Sana University graduates demonstrated about not being offered jobs by the government upon graduation. In accordance with the Egyptian model, there is an expectation of government patronage.

\section{The new elite consider university edu- cation abroad to be superior.}

Expert knowledge obtained at foreign universities forms part of new practices that create both uniformity and competition among the new and the old elites. New hierarchical divisions are emerging between the well-to-do members of the old and new elites who are able to afford education abroad and an impoverished majority. The old elite has abandoned religious studies for career purposes; their tradition of scholarship predisposes them to obtain scholarships abroad and to succeed in their careers.

The political dimension of conflicts about knowledge is most apparent in the sphere of law and the dual higher education system that has emerged since the 1970s. During the Imamate, jurisprudence was the bastion of the welltrained elite. After the revolution, men who studied secular law in countries such as Egypt competed with and often replaced Shariah-trained judges, challenging their mo- nopoly over the judiciary. Both these groups of legal experts have a common enemy: Neo-Salafi Islamists, who aided the government in defeating socialism, have since the late 1970s aspired to eliminate secular (and Shii) elements from the judiciary and the education system. New religious teaching institutions (al-Maahid al-Ilmiyyah) that enjoy Saudi sponsorship and the patronage of powerful politicians, among them the leader of the Islah party and speaker of Parliament, Shaykh Abdullah al-Ahmar, have not yet been brought under government control. As a response to Islamist agitation, the religious content of the government-sponsored curricula has been reinforced. Students' acquisition of different models of history at the various institutions raises questions about the role of education in the production of a unified nation-state. The university's role in the democratization process has been called into question with the growing influence of the Islamists.

In conclusion, since the early 20th century there has been a marked trend toward centralization and greater control of education, a process which accompanied by changes in the organization and perceptions of knowledge. The struggle during the Imamate over these issues has continued in the republic in different guises. The Yemeni nationalist project is subject to many different claims and appeals that are based on diverse sources of knowledge.

\section{Note}

1. Brinkley Messick, The Calligraphic State (Berkeley: University of California Press, 1993), 101-14, 120, 122.

\title{
Higher Education in Egypt: The Realpolitik of Privatization
}

\section{Iman Farag}

Iman Farag is a researcher at the Centre d'Études et de Documentation Économique, Juridique et Sociale (CEDEJ) in Cairo. Address: CEDEJ, $P O B$ 392, Muhammed Farid, Cairo, Egypt. E-mail: <cedej@idsc.gov.eg>.

$\mathrm{B}$ y the academic year 1999-2000, about 1.5 million students were attending Egypt's 12 state universities and their 7 branches. To this number, one has to add the newcomers - that is, 4 private universities attended by about 6,000 students. In spite of these small figures, private universities have rapidly acquired a major political significance as the most striking and controversial aspect of the privatization of higher education.

\section{Forms of Privatization}

In recent years, state universities have introduced foreignlanguage programs. These programs, for which tuition is charged, allow students originally from private foreignlanguage schools to follow a curriculum partly in English or French. This ensures a higher-quality education, and better job prospects for those individuals already endowed with economic and cultural capital. Furthermore, some private schools are authorized to award diplomas from foreign secondary schools. Their students are thus able to avoid the nightmare of the Thanawiyya 'Amma (nationwide final secondary school examination), which simplifies access to university.

The ongoing debate over the new universities law, which is still under discussion, may illustrate the shifting equilibrium between state responsibilities and privatization that characterizes the current situation. The new law is supposed to replace the 1972 universities law and provide unified legislation for all the sectors of higher education: state and private universities, al-Azhar University, and higher institutes. Supporters of private higher education perceive this coming law as a way for the state to control private initiatives, while it is seen by public education supporters as a way to normalize and legitimize private higher education by including it within the larger body of na- 
tional education. In the Egyptian case, both perspectives seem valid.

Historically, private schools have emerged as part of this national education system and hence as legitimate alternatives that are needed in order to create a qualified national elite. At present, with the exception of the American University of Cairo, all private higher education institutions are seen as a way to sell degrees to those who can afford them. In January 1999, private universities, especially those in the medical specialties, won a legal battle against the Physicians' Syndicate (Naqabat al-Atibba'), which had claimed that only graduates of a state university should be authorized to practice medicine. There are 18 private universities still waiting for official authorization, among them French and German collaborations. New categories are emerging that will distinguish between private institutions and branches of foreign universities. The latter are often presented as a "national threat," but their founders argue that they will be totally Egyptian universities, as most of their sponsors and shareholders are Egyptian.

\section{At present, with the exception of the American University of Cairo, all private higher education institutions are seen as a way to sell degrees to those who can afford them.}

The fact that education reproduces existing social inequalities is in itself not a new discovery. Studies on the social class and educational backgrounds of state university students have shown that in spite of the fact that higher education is free, most students in high-status faculties attended prestigious private secondary schools. This is because graduates of such schools generally do very well on their final secondary exams, which ensures access to what are considered the elite faculties. What does seem new is the institutionalization of privatized higher education and the fact that arguments about equity are often rejected as belonging to the past. However, the so-called "rationalization of free education" will not take place immediately or rapidly. State involvement in education is no longer a means of promoting social goals but rather of dealing with current constraints. In the official discourse, education is part of "national defense." Along with internal security, external defense, and protection of private property, privatization fits in with the concept of the minimal state. Increasingly, concerns about the quality and standards of learning provided by mass higher education seem to be disconnected from those about equity, as if these competing goals involved different social groups. According to some, higher education no longer has to address social expectations or the quest for knowledge, but rather the job market. The variable that is supposed to adapt is higher education, rather than the job market, which is a "given." Here too, an "invisible hand" adjusts development goals to the market-a market which is no longer national but globalized.

\section{Studies on the social class and educa- tional backgrounds of state university students have shown that in spite of the fact that higher education is free, most students in high-status faculties at- tended prestigious private secondary schools.}

\section{Realpolitik and Expectations}

The whole question of private higher education should be considered in relation to the issue of unemployment. University degree holders are not the ones who suffer the most from unemployment, but their expectations carry significant political weight. It seems that the more educated a group is the more legitimate its expectations are perceived as being. Within the context of the overall decline of the middle classes, which are basically characterized by the attainment of knowledge, some people may argue that higher education is losing part of its "comparative advantage" and that investing in higher education is no longer relevant or productive with regard to salaries, working conditions, career opportunities, and social status. However, such an "objective" approach overlooks the fact that people's expectations are not necessarily the same as those of the decision makers, the latter usually being highly educated individuals. Higher education continues to be part of individual and group hopes and dreams, which cannot be reduced to material wealth but also have to do with equality and dignity.

In early 1999, a high-level committee was set up to focus on the development of higher education. The committee is made up of subcommittees responsible for structural developments and diversity, performance assessment, higher education systems, graduate studies, economics and finance, and social needs and education. One may wonder if this new committee's approach to higher education will be sensitive to the expectations of those who do not yet have access to it. 